\title{
THE MEDIATING EFFECTS OF VALUE ON SERVICE QUALITY-SATISFACTION RELATIONSHIP IN MALAYSIAN TOURISM INDUSTRY
}

\author{
See-Ying Kwok* \\ Universiti Tunku Abdul Rahman \\ Ahmad Jusoh \\ Universiti Teknologi Malaysia \\ Zainab Khalifah \\ Universiti Teknologi Malaysia
}

\begin{abstract}
The ways to maintain and increase customer satisfaction are always the concern of business providers because high satisfaction is closely related to the customers' positive word of mouth, revisit intentions, and loyalty; which are the key for the success of long term businesses in today's customer-focused industry. For that reason, more satisfaction studies, especially on the elements that contribute to higher satisfaction level are needed. Previous researches discovered several explanatory predictors to satisfaction. Nevertheless, in this study, only two variables, i.e. service quality and value were chosen as the antecedent variables associated to satisfaction among international tourists in the context of Malaysian tourism. This study further focused on examining whether service quality has an indirect impact on satisfaction through value, i.e. the mediator effect. The relationships proposed were analysed with structural equation modelling (SEM) analysis using the data gathered from 301 international tourists that have travelled to Malaysia. The findings indicated that both service quality and value are the significant predictors that influence tourist satisfaction. Additionally, the results also indicated that value plays a mediator role in the service quality-satisfaction relationship in the tourism context.
\end{abstract}

Keywords: Satisfaction; Value; Service Quality; Tourist.

\section{INTRODUCTION}

The tourism industry in Malaysia is continuously developing. The statistical data shows that international tourist arrivals in Malaysia has increased from 16.43 million in year 2005 to 25.70 million in year 2015, while the tourist receipts of the same period has increased from RM32.0 billion to RM69.1 billion (Tourism Malaysia, 2017). A successful tourism business will deliver greater revenues to the host country, especially for the countries with abundant tourism resources. For instance, in year 2012 alone, tourist receipts contributed $12.5 \%$ of Malaysia's Gross Domestic Product, making it the second largest foreign exchange earners in the country (Prime Minister's Department, 2014). Even though the industry achieves great success, merely maintaining things as they are insufficient for long term development. Additional efforts should be taken to sustain and further grow the tourism business in Malaysia. There would be no tourism without tourists, and hence the tourism industry stakeholders should focus more on the tourist's perspective.

*Corresponding author: Faculty of Business and Finance, Universiti Tunku Abdul Rahman, 31900 Kampar Perak. Malaysia. Email: s.ying0525@yahoo.com 
Often, the survival or even the success of an organization depends on the extent the organization is able to meet the customers' needs and requirements, that is whether the service provider has managed to satisfy its customer or not. A satisfied customer is found to reward the company through repurchase, sharing positive word-of-mouth and will eventually lead to loyalty in the long run (Bruwer, 2014; Hoffman \& Bateson, 2011). On the contrary, a dissatisfied customer is more likely to be found sharing their bad experiences with others (Hoffman \& Bateson, 2011; Hoyer \& Maclnnis, 2010), which will discourage new customers. Subsequently, how to satisfy the customers turn out to be the key concern of all business operators and the tourism business operators are not an exemption. Hence, instilling better understanding of related factors that create tourist satisfaction from the tourist's point of view is essential.

Past researches have shown that both service quality (e.g. González, Comesaña, \& Brea, 2007; Ngo \& Nguyen 2016; Subrahmanyam \& Raja, 2016; Spreng \& Mackoy, 1996) and value (e.g. Andreassen \& Lindestad, 1998; Bolton \& Drew, 1991; Patterson \& Spreng, 1997; Woodruff, 1997) are positively related to customer satisfaction. Besides that, a number of past researches (e.g. Chang \& Wang, 2011; Gallarza, Saura, \& Moreno, 2013; Gera, 2013; Jen, Tu, \& Lu, 2011; Lai \& Chen, 2011; Yu et al., 2014) have also revealed that service quality and value are positively correlated. Accordingly, instead of merely assuming that service quality has only the direct influence on customer satisfaction, the indirect effects, i.e. the mediator effects through value may take place as well. This means that the relationships between service quality, value, and satisfaction could be more complex and might consist of intermediate interactions such as the mediating effects and thus warrant further examination. For that reason, the main purpose of this study is to examine whether value mediates the service quality-satisfaction relationship, particularly in the Malaysian tourism context.

\section{MAJOR CONCEPTS DEFINITION}

\subsection{Satisfaction}

Oliver (1997, p. 13) defined customer satisfaction as "the consumer fulfilment response. It is a judgment that a product or service feature, or the product or service itself, provided (or is providing) a pleasurable level of consumption-related fulfilment, including levels of under-or over-fulfilment'. Thus, satisfaction pertains to one's comparison between the perceived performance of the products and/or services in relation to his or her expectations (Ooi, Lin, Tan, \& Chong, 2011). According to the expectancy disconfirmation theory, the customer is satisfied when the actual performance meets or exceeds their expectation. If not, when expectation is higher than the actual performance, it brings to a negative disconfirmation; a dissatisfied customer. Subsequently, this study defined satisfaction as the tourist's feelings in terms of their liking and disliking on their visit to Malaysia based on their comparison of expectation to the actual trip's experience.

\section{2. $\quad$ Service quality}

Generally, it is widely accepted that service quality depends on the degree of the actual service performance in meeting the customer's needs and expectations (Asher, 1996; Grönroos, 1990; Presbury, Fitzgerald, \& Chapman, 2005); hence, service quality can be understood as the conformance of the customer's requirements to the service received (Chakrabarty, Whitten, \& Green, 2007). The customer is the key evaluator of the service quality where they determine the success of a product or service (Kelesbayev, Kalykulov, Yermankulova, Dandayeva, \& Aymurzayeva, 2015; Peter \& Donnelly, 2013a, 2013b; Swarbrooke \& Horner, 2007). Subsequently, customer surveys are the most used tools in measuring 
service quality thus far (Homburg, Kuester, \& Krohmer, 2013). In a nutshell, service quality in this study is best defined as the tourist's assessment on the overall quality of services they perceived throughout their visit to Malaysia.

\subsection{Value}

McDougall and Levesque (2000, p.393) suggested that value is the "benefits received relative to costs", which is consistent with Zeithaml's viewpoint who defined value as "consumer's overall assessment of the utility of a product (or service) based on perceptions of what is received and what is given" (1988, p.14). Accordingly, value can be comprehended as the monetary prices and/or non-monetary costs, i.e. time, energy, effort, search, and psychological costs that one has to sacrifice in acquiring the beneficial components, i.e. product or service quality, brand and functions from the services or products (Bajs, 2015; Jen, et al., 2011; Lien, Wen, \& Wu, 2011). Hence, value can be understood as the trade-off between total benefits gained and total sacrifices or costs (Holbrook, 1994; Peter \& Donnelly, 2013a) to obtain a service or product (Eid \& El-Gohary, 2015; Hu, Kandampully, \& Juwaheer, 2009; Mahrokh Mokhtaran \& Mohebi, 2015). In short, value is viewed as the overall sacrifices incurred in comparison to the benefits received by the international travellers during their visit to Malaysia.

\section{HYPOTHESES DEVELOPMENT}

According Parasuraman, Zeithaml, and Berry's (1985) perspective, satisfaction level is influenced by the gap between service perception and expectation. For instance, a better fit between service perceptions with service performance will reduce the gap, leading to higher perceived service quality, and consequently higher satisfaction level (Asher, 1996; Ekinci, 2004; Parasuraman, et al., 1985; Parasuraman, Zeithaml, \& Berry, 1994). The disconfirmation theory supports the gap's view, meaning that when perceptions meet or exceed quality expectation, positive disconfirmation is formed and the customer is satisfied. Otherwise, the customer is dissatisfied, suggesting a negative disconfirmation when perceived quality is lower than expectation. In previous researches, a positive relationship between service quality and satisfaction is supported (e.g. Cheng \& Rashid 2015; Ekinci, 2004; Ngo \& Nguyen 2016; Subrahmanyam \& Raja, 2016). Therefore, it is rational to accept that higher service quality will lead to higher satisfaction level and hence, the first hypothesis is proposed as following:

H1: Service Quality is positively associated to Satisfaction.

Value and satisfaction are two closely related but distinct concepts (Ferrell \& Hartline, 2014; Raza, Siddiquei, Awan, \& Bukhari, 2012; Woodruff, 1997). The level of satisfaction of a service or product is claimed to be relative to one's expectation, and one can hold expectation about quality or value or both at the same time (Ferrell \& Hartline, 2011, 2014). Accordingly, the concept of satisfaction is difficult to separate from quality and value to some extent. The positive and direct relationship between value and customer satisfaction is supported in past researches. (Chang \& Wang, 2011; Chen \& Chen, 2010; Clemes, et al., 2011; Gallarza, et al., 2013; Malik, 2012; Wu \& Li, 2014). This means that rather than service quality alone, satisfaction can be assessed through the value construct as well (Chang \& Wang, 2011; Clemes, Gan, \& Ren, 2011; Jen, et al., 2011; Lai \& Chen, 2011; Minghetti \& Celotto, 2013; Raza, et al., 2012). Therefore, the second hypothesis is proposed:

$H 2$ : Value is positively associated to Satisfaction. 
Both service quality and value are two important antecedent factors to satisfaction (Ferrell \& Hartline, 2014; Minghetti \& Celotto, 2013). In addition, these two constructs are correlated, in which service quality is associated with value (Jen, et al., 2011; Lai \& Chen, 2011). A positive relationship between service quality and value has been revealed in previous studies (e.g. Chang \& Wang, 2011; Cronin, Brady, \& Hult, 2000; Gallarza, et al., 2013; Gera, 2013; Kang \& Wang, 2009; Lai \& Chen, 2011; Yu, et al., 2014). Subsequently, the third hypothesis is proposed:

H3: Service Quality is positively associated to Value.

The findings from past researches indicate that service quality has the major influence over satisfaction, while value is an alternative that leads to satisfaction as well (Chang \& Wang, 2011; Fornell, Johnson, Anderson, Cha, \& Bryant, 1996; Razavi, Safari, Shafie, \& Khoram, 2012; Wang, Zhang, Gu, \& Zhen, 2009). In addition, value also equals to perceived service quality relative to price (Kashyap \& Bojanic, 2000; Oh, 2000), and hence, it is sensible to believe that service quality may be one of the many factors that influence "value" and that it is value that determines the overall satisfaction level (Bolton \& Drew, 1991; Sweeney, Soutar, \& Johnson, 1997; Woodruff, 1997). This means that service quality influences value prior to having an impact on the satisfaction level later (Baines, Fill, \& Page, 2011; McDougall \& Levesque, 2000).

Sheth, Newman, and Gross (1991) further suggested that regardless of the dimensions in the value construct, value functions as a mediator between service quality and satisfaction, and this perspective is supported by other researchers (e.g. Cronin, et al., 2000; Lai, 2015; Malik, 2012; Murray \& Howat, 2002; Sheth, et al., 1991). For instance, a partial mediator role of value between service quality and satisfaction has been evidenced in Malik's (2012) study in which the sample comprised of respondents from the banking, transport, courier, and telecommunication sectors. Furthermore, a recent study conducted by Lai (2015) has empirically evidenced the mediator role of value in the relationship between service quality and satisfaction at Hong Kong-style tea restaurants. Accordingly, value is proposed as a mediator variable in the relationship between service quality and satisfaction in this paper.

H4: Value mediates the relationship between Service Quality and Satisfaction.

\section{THE METHODOLOGY AND DATA ANALYSIS}

The tourists that travelled to Malaysia made up the population of this study. A representative sample was drawn from the international tourist groups travelling to Malaysia, utilising the multistage sampling technique due to the large population. First, the samples were stratified based on ASEAN tourists and nonASEAN tourists. Secondly, the convenience sampling technique was used to draw the samples at selected tourism destinations in Malaysia. A set of questionnaire was used as the instrument for data collection. Service quality was measured with 22 items in a 5-point Likert scale adapted from SERVQUAL. Meanwhile, Value (10 items) and Satisfaction (5 items) were measured with the 5-point Likert scale. The demographic background of the respondents was also assessed.

400 self-administrated questionnaires were distributed to willing respondents during on-site surveys after a few screening questions. This was done in order to ensure that the respondents were qualified to provide usable and accurate data for this research. The qualified respondents were then requested to answer and return the questionnaires on the spot. 301 completed questionnaires were analysed with SPSS and AMOS software upon removing 3 incomplete questionnaire. 


\subsection{Respondents' Profile}

The respondents' profile provided a basic concept of the respondents engaged in the survey (refer to Table 1). A total of 198 respondents from non-ASEAN countries and 103 respondents from ASEAN countries participated in this research. Besides that, 56.8\% of the respondents were female $(\mathrm{n}=171)$ and $43.2 \%$ were male respondents $(n=130)$. The results also indicated that $47.8 \%$ or 144 respondents were married. Other than that, tourists aged 40 and below made up the majority of the tourist groups. Based on the statistical results, most of the tourists visited Malaysia for vacation purposes, which was accounted by 238 out of 301 respondents (79.1\% of the respondents). Moreover, the statistical results showed that the tourists preferred to travel on their own (86.4\%) rather than travelling with a tour package (13.6\%).

Table 1: Respondents' Profile

\begin{tabular}{|c|c|c|c|c|c|}
\hline Items & Frequency & Percent, \% & Items & Frequency & Percent, \% \\
\hline Nationality & & & Major Purpose of Visit & & \\
\hline ASEAN & 103 & 34.2 & Holiday & 238 & 79.1 \\
\hline Non-ASEAN & 198 & 65.8 & Business & 11 & 3.7 \\
\hline Gender & & & Official Mission & 11 & 3.7 \\
\hline Male & 130 & 43.2 & Visiting Friends and Relatives & 22 & 7.3 \\
\hline Female & 171 & 56.8 & Conference & 2 & 0.7 \\
\hline Age & & & Others & 17 & 5.6 \\
\hline 30 years old and below & 137 & 45.5 & Mode of Visit & & \\
\hline 31 years old -40 years old & 107 & 35.5 & Tour Package & 41 & 13.6 \\
\hline 41 years old -50 years old & 36 & 12.0 & Self-guided Tour & 260 & 86.4 \\
\hline 51 years old -60 years old & 12 & 4.0 & & & \\
\hline 61 years old and above & 9 & 3.0 & & & \\
\hline \multicolumn{6}{|l|}{ Marital Status } \\
\hline Single & 119 & 39.5 & & & \\
\hline Married & 144 & 47.8 & & & \\
\hline Others & 38 & 12.6 & & & \\
\hline
\end{tabular}

\subsection{Exploratory and Confirmatory Factor Analysis}

The Exploratory Factor Analysis (EFA) was firstly conducted using the Principal Component Analysis with Variamax rotation. The questionnaire items were successfully extracted into six components (factor loading $\geq 0.4$ ). Out of the six components extracted, four components are Service Quality dimension, a component for Value and Satisfaction respectively. The model was acceptable with initial eigenvalues above 1.0, KMO $>0.7$, Bartlett's test value of $p<0.01$ and explained a total of $69.05 \%$ variance $(>60 \%)$. Afterward, Confirmatory Factor Analysis (CFA) was conducted based on the EFA results. The final measurement model provided a good fit to the sample data $\left(\chi^{2}=497.656, \mathrm{df}=221, \chi^{2 /} \mathrm{df}=2.252\right)$ upon the deletion of the poor load items and minor modification. The GFI was .877 , AGFI $=.847$, CFI $=.938$, TLI $=.929$ and $\mathrm{RMSEA}=.065$. The composite reliability $(\mathrm{CR})$ values exceeded the required value of 0.7 , and

Table 2: Discriminant Validity, Convergent Validity and Composite Reliability

\begin{tabular}{lccccc}
\hline \hline & \multicolumn{2}{c}{ Discriminant Validity } & Convergent Validity, & $\begin{array}{c}\text { Composite Reliability, } \\
\text { AVE }>\mathbf{0 . 5}\end{array}$ \\
\cline { 2 - 4 } & Value & Satisfaction & Service Quality & AV.7 \\
\hline Value & $\mathbf{0 . 7 9 7}$ & & & 0.635 & 0.895 \\
Satisfaction & 0.610 & $\mathbf{0 . 8 1 9}$ & & 0.671 & 0.890 \\
Service Quality & 0.460 & 0.440 & $\mathbf{0 . 7 4 1}$ & 0.549 & 0.824 \\
\hline \hline
\end{tabular}


the AVE value of the latent factors ranged from 0.549 to $0.671(>0.5)$ as shown in Table 2, which indicated that both reliability and convergent validity were achieved. Similarly, the discriminant validity was supported with the squared root of AVE values, which were greater than the inter-correlation coefficients among the constructs.

\subsection{Structural Analyses}

The relationship between Service Quality and Satisfaction was examined using structural analysis. Service Quality (a second-order factor with four first-order factors) was first regressed to Satisfaction (a first-order factor). The goodness-of-fit indices showed that Model 1 fitted the data adequately. The chi-square/df was $2.051\left(\chi^{2}=264.634\right.$, df $\left.=129\right)$. The GFI was $.913, \mathrm{AGFI}=.885, \mathrm{CF}=.957$, TLI $=.948$, and RSMEA $=.059$. The model that fitted the criteria for the path model was satisfactory, thus Model 1 was accepted to fit the data. A positive and significant relationship ( $\mathrm{rc}=0.44, \mathrm{CR}=5.72$ ) was found between Service Quality and Satisfaction (as shown in Table 3: Model 1).

Table 3: Mediator Test of Value Between Service Quality-Satisfaction

\begin{tabular}{clccc}
\hline \hline Model & \multicolumn{1}{c}{ Relationships } & Standardised Estimate (Rc) & Cr & Result \\
\hline $\mathbf{1}$ & Service Quality - Satisfaction & $.44^{* *}$ & 5.72 & Supported \\
$\mathbf{2}$ & Service Quality - Value & $.46^{* *}$ & 6.30 & Supported \\
& Service Quality - Satisfaction & $.20^{* *}$ & 2.96 & Supported \\
& Value - Satisfaction & $.51^{* *}$ & 7.62 & Supported \\
\hline \hline
\end{tabular}

Note: $* \mathrm{p}<0.05 ; * * \mathrm{p}<0.01$ (one-tailed test)

Table 4: Direct Effects and Indirect Effects for Value as Mediator

\begin{tabular}{llc}
\hline \hline \multicolumn{1}{c}{ Effect } & \multicolumn{1}{c}{ Relationships } & Standardised Estimate (Rc) \\
\hline Direct Effects & Service Quality - Satisfaction & .20 \\
& Service Quality - Value & .46 \\
& Value Satisfaction & .51 \\
Indirect Effects & Service Quality - Value - Satisfaction & .23 \\
\hline Total effects & Service Quality - Value - Satisfaction & .44 \\
\hline \hline
\end{tabular}

Next, the construct of Value (a first-order factor) was included as the mediator variable between Service Quality and Satisfaction in Model 2. The goodness-of-fit indices for the model indicated a good fit to the data $\left(\chi^{2} / \mathrm{df}=2.252, \chi^{2}=497.656, \mathrm{GFI}=.877, \mathrm{AGFI}=.847, \mathrm{TLI}=.929, \mathrm{CFI}=.938\right.$, and $\left.\mathrm{RMSEA}=.065\right)$. The association between Service Quality and Satisfaction was reduced but remained significant when the "Value" construct was added which denoted a partial mediator effect (as shown in Table 3). Thus, it is reasonable to conclude that Value mediates the relationship between Service Quality and Satisfaction. Subsequently, all four hypotheses proposed are supported.

\section{DISCUSSION AND IMPLICATIONS}

The descriptive analysis on the profile of the respondents' background showed that the tourists in the group age of 40 years old and below were the majority of the tourists in this study. The results also indicated a significant number of respondents visiting Malaysia mainly for vacation purposes and they prefer to travel on their own rather than follow scheduled tours arranged by tour agencies. Overall, these results indicated that the respondents of this research were basically young tourists who prefer to plan the itinerary on their own for their holiday visit to Malaysia. 
The Structural Equation Modelling (SEM) analysis showed that "value" played a mediator role in the relationship between service quality and tourist satisfaction. The results suggested that a simple and oneto-one relationship in the past was insufficient in illustrating the interactions of these variables. There is empirical evidence that the inclusion of value into the model will reduce the association between service quality and satisfaction. Note that the indirect effect of service quality on satisfaction via value ( $\mathrm{rc}=0.23$ ) was higher than the direct effect of service quality on satisfaction $(\mathrm{rc}=0.20)$. Hence, instead of the role as a direct antecedent to satisfaction creation, service quality had an indirect influence on satisfaction through value as well, which demonstrated a mediator effect. The research findings in this study have thus provided further empirical evidence to support and validate the role of "value" as a mediator in the relationship between service quality and satisfaction which is discovered in previous researches (e.g. Lai, 2015; Malik, 2012 and etc.).

In other words, this study provided implications to the tourism service providers through clarifying the impacts of both service quality and value as the contributors of tourist satisfaction. The empirical findings in this study suggested that in order to improve tourists' satisfaction, tourism service providers have to start by improving the quality of services provided. Supplementary to the direct impact on tourists' satisfaction level, an enhancement of the quality of the services delivered was found to be able to increase the customers' (or tourists) satisfaction level indirectly through the improved tourists' perceived value. Consequently, the tourism service providers are urged to pay more attention in the aspect of controlling the quality of services delivered. In addition to that, consistent monitoring and evaluation of customer-related measures can help tourism service providers to deliver the products/services which satisfy tourists the most.

Besides that, the empirical findings of this research suggested that the service personnel are the primary element that determines the perceived service quality among the tourists. As a service-oriented industry, the service crews play relatively important role in satisfying the customers. Therefore, the tourism service providers must first content their internal customer (or staff) which will subsequently result in a better job performance that eventually leads to higher customer satisfaction level. Accordingly, the process of service personnel recruitment and training alongside designing appropriate reward system are thus essentially important to the management in producing well-performed staff.

\section{LIMITATIONS SUGGESTION FOR FUTURE RESEARCH}

This study only focused on the tourism industry in Malaysia. Each country varies from geographical, cultural and other aspects and the outcomes of the study may vary and may not be applicable for other countries. Similarly, each industry has their own characteristics that make it unique from other industries and hence the study in a specific industry is insufficient. Subsequently, further studies have to be carried out in other countries and/or industries to validate the role of "value" as a mediator in the relationship between service quality and satisfaction.

\section{REFERENCES}

Andreassen, T. W., \& Lindestad, B. (1998). Customer loyalty and complex services: the impact of corporate image on quality, customer satisfaction and loyalty for customers with varying degrees of service expertise. International Journal of Service Industry Management, 9(1), 7-23.

Asher, M. (1996). Managing quality in the service sector. London: Kogan Page.

Baines, P., Fill, C., \& Page, K. (2011). Marketing (2nd ed.). New York: Oxford University Press. 
Bajs, I. P. (2015). Tourist Perceived Value, Relationship to Satisfaction, and Behavioral Intentions: The Example of the Croatian Tourist Destination Dubrovnik. Journal of Travel Research, 54(1), 122134. doi: $10.1177 / 0047287513513158$

Bolton, R. N., \& Drew, J. H. (1991). A multistage model of customers' assessments of service quality and value. Journal of Consumer Research, 17(4), 375-384.

Bruwer, J. (2014). Service Quality Perception and Satisfaction: Buying Behaviour Prediction in an Australian Festivalscape. International Journal of Tourism Research, 16(1), 76-86. doi: 10.1002/jtr.1901

Chakrabarty, S., Whitten, D., \& Green, K. (2007). Understanding service quality and relationship quality in IS outsourcing: Client orientation \& promotion, project management effectiveness, and the tasktechnology-structure fit. Journal of Computer Information Systems, 48(2), 1-15.

Chang, H. H., \& Wang, H.-W. (2011). The moderating effect of customer perceived value on online shopping behaviour. Online Information Review, 35(3), 333-359. doi: 10.1108/14684521111151414

Chen, C.-F., \& Chen, F.-S. (2010). Experience quality, perceived value, satisfaction and behavioral Intentions for heritage tourists. Tourism Management, 31(1), 29-35.

Cheng, B. L., \& Rashid, Z. A. (2015). Interrelationships of Service Quality, Customer Satisfaction, Corporate Image and Customer Loyalty of Malaysian Hotel Industry. In V. Katsoni (Eds.), Cultural Tourism in a Digital Era (pp. 37-38). Switzerland: Springer International Publishing.

Clemes, M. D., Gan, C., \& Ren, M. (2011). Synthesizing the Effects of Service Quality, Value, and Customer Satisfaction on Behavioral Intentions in the Motel Industry: An Empirical Analysis. Journal of Hospitality \& Tourism Research, 35(4), 530-568. doi: 10.1177/1096348010382239

Cronin, J. J., Brady, M. K., \& Hult, G. T. M. (2000). Assessing the effects of quality, value, and customer satisfaction on consumer behavioral intentions in service environments. Journal of Retailing, 76(2), 193-218.

Eid, R., \& El-Gohary, H. (2015). Muslim Tourist Perceived Value in the Hospitality and Tourism Industry. Journal of Travel Research, 54(6), 774-787. doi: 10.1177/0047287514532367

Ekinci, Y. (2004). An investigation of the determinants of customer satisfaction. Tourism Analysis, 8(2-4), 197-203.

Ferrell, O. C., \& Hartline, M. D. (2011). Marketing Strategy (5th ed.). US: South-Western, Cengage Learning.

Ferrell, O. C., \& Hartline, M. D. (2014). Marketing Strategy. Text and Cases (6th ed.). US: South-Western, Cengage Learning.

Fornell, C., Johnson, M. D., Anderson, E. W., Cha, J., \& Bryant, B. E. (1996). The American customer satisfaction index: nature, purpose, and findings. Journal of Marketing, 60(4), 7-18.

Gallarza, M. G., Saura, I. G., \& Moreno, F. A. (2013). The quality-value-satisfaction-loyalty chain: relationships and impacts. Tourism Review, 68(1), 3-20.

Gera, R. (2013). Evaluating the relationship of online service quality dimensions with satisfaction, value and behavioral. African Journal of Business Management, 7(10), 754-761. doi: 10.5897/AJBM11.675

González, M. E. A., Comesaña, L. R., \& Brea, J. A. F. (2007). Assessing tourist behavioral intentions through perceived service quality and customer satisfaction. Journal of Business Research, 60(2), 153-160. doi: 10.1016/j.jbusres.2006.10.014

Grönroos, C. (1990). Relationship approach to marketing in service contexts: the marketing and organizational behaviour interface. Journal of Business Research, 20(1), 3-11.

Hoffman, K. D., \& Bateson, J. E. G. (2011). Services marketing: Concepts, strategies, and cases (4th ed.). USA: South-Western Cengage Learning.

Holbrook, M. (1994). The nature of customer value: an anthology of services in the consumption experience. CA: Sage Publications, Thousand Oaks. 
Homburg, C., Kuester, S., \& Krohmer, H. (2013). Marketing management : a contemporary perspective (2nd ed.). London: McGraw-Hill Higher Education.

Hoyer, W. D., \& Maclnnis, D. J. (2010). Consumer Behavior (5th ed.). USA: South-Western, Cengage Learning.

Hu, H.-H. S., Kandampully, J., \& Juwaheer, T. D. (2009). Relationships and impacts of service quality, perceived value, customer satisfaction, and image: an empirical study. The Service Industries Journal, 29(2), 111-125. doi: 10.1080/02642060802292932

Jen, W., Tu, R., \& Lu, T. (2011). Managing passenger behavioral intention: an integrated framework for service quality, satisfaction, perceived value, and switching barriers. Transportation, 38(2), 321-342. doi: 10.1007/s11116-010-9306-9

Kang, H. C, \& Wang, Y. W. (2009). The relationships among sea-food restaurant service quality, perceived value, customer satisfaction and behavioral intentions using structural equation models: A case of Pengh. Paper presented at the $9^{\text {th }}$ International Conference on Electronic Business, Macau, China.

Kashyap, R., \& Bojanic, D. C. (2000). A structural analysis of value, quality, and price perceptions of business and leisure travelers. Journal of Travel Research, 39(1), 45-53.

Kelesbayev, D., Kalykulov, K., Yermankulova, R., Dandayeva, B., \& Aymurzayeva, A. (2015). Determination of Quality Requirements in Tourism Management and Finance Departments of Akhmet Yassawi University by Kano Model. Mediterranean Journal of Social Sciences, 6(3), 3442. doi: 10.5901/mjss.2015.v6n3s1p34

Lai, K. W. (2015). The Roles of Value, Satisfaction, and Commitment in the Effect of Service Quality on Customer Loyalty in Hong Kong-Style Tea Restaurants. Cornell Hospitality Quarterly, 56(1), 118 138. doi: 10.1177/1938965514556149

Lai, W.-T., \& Chen, C.-F. (2011). Behavioral intentions of public transit passengers - The Roles of Service Quality, Perceived Value, Satisfaction and Involvement. Transport Policy, 18(2), 318-325. doi: 10.1016/j.tranpol.2010.09.003

Lien, C.-H., Wen, M.-J., \& Wu, C.-C. (2011). Investigating the Relationships among E-Service Quality, Perceived Value, Satisfaction, and Behavioral Intentions in Taiwanese Online Shopping. Asia Pacific Management Review, 16(3), 211-223.

Mahrokh Mokhtaran, M. F., Mohammad Reza Jalilvand \& Majid, \& Mohebi. (2015). The Effect of Service Climate on Perceived Service Value and Behavioral Intentions: The Mediating Role of Service Quality Asia Pacific Journal of Tourism Research, 20(4), 472-486. doi: 10.1080/10941665.2014.889029

Malik, S. U. (2012). Customer Satisfaction, Perceived Service Quality and Mediating Role of Perceived Value. International Journal of Marketing Studies, 4(1), 68-76. doi: doi:10.5539/ijms.v4n1p68

McDougall, G. H., \& Levesque, T. (2000). Customer satisfaction with service: Putting perceived value into the equation. Journal of Services Marketing, 14(5), 392-410.

Minghetti, V., \& Celotto, E. (2013). Measuring Quality of Information Services: Combining Mystery Shopping and Customer Satisfaction Research to Assess the Performance of Tourist Offices. Journal of Travel Research, 53(5), 564-580. doi: 10.1177/0047287513506293

Murray, D., \& Howat, G. (2002). The Relationships among Service Quality, Value, Satisfaction, and Future Intentions of Customers at an Australian Sports and Leisure Centre. Sport Management Review, 5(1), 25-43.

Ngo, V. M., \& Nguyen, H. H. (2016). The Relationship between Service Quality, Customer Satisfaction and Customer Loyalty: An Investigation in Vietnamese Retail Banking Sector. Journal of Competitiveness, 8(2), 103-116. doi: 10.7441/joc.2016.02.08

Oh, H. (2000). The effect of brand class, brand awareness, and price on customer value and behavioral intentions. Journal of Hospitality and Tourism Research, 24(2), 136-162. 
Oliver, R. L. (1997). Satisfaction: A behavioral perspective on the consumer. New York: McGraw-Hill.

Ooi, K.-B., Lin, B., Tan, B.-I., \& Chong, A. Y.-L. (2011). Are TQM Practices Supporting Customer Satisfaction and Service Quality? Journal of Services Marketing, 25(6), 410-419.

Parasuraman, A., Zeithaml, V. A., \& Berry, L. L. (1985). A conceptual model of service quality and its implications for future research. Journal of Marketing, 49(Fall), 41-50.

Parasuraman, A., Zeithaml, V. A., \& Berry, L. L. (1994). Alternative scales for measuring service quality: a comparative assessment based on psychometric and diagnostic criteria. Journal of Retailing, 70(3), 201-230.

Patterson, P. G., \& Spreng, R. A. (1997). Modeling the relationship between perceived value, satisfaction and repurchase intentions in a business-to-business, services context: an empirical examination. Journal of Service Industry Management, 8(5), 414-434.

Peter, J. P., \& Donnelly, J. J. H. (2013a). Marketing management : knowledge and skills (11th ed.). New York: McGraw-Hill Irwin.

Peter, J. P., \& Donnelly, J. J. H. (2013b). A Preface to Marketing Management (13th ed.). New York: McGraw-Hill Irwin.

Presbury, R., Fitzgerald, A., \& Chapman, R. (2005). Impediments to improvements in service quality in luxury hotels. Managing Service Quality, 15(4), 357-373.

Prime Minister's Department. (2014). Economic Transformation Programme Annual Report 2013. Malaysia: Performance Management and Delivery Unit (PEMANDU).

Raza, M. A., Siddiquei, A. N., Awan, H. M., \& Bukhari, K. (2012). Relationship between Service Quality, Perceived Value, Satisfaction and Revisit Intention in Hotel Industry. Interdisciplinary Journal of Contemporary Research In Business, 4(8), 788-805.

Razavi, S. M., Safari, H., Shafie, H., \& Khoram, K. (2012). Relationships among Service Quality, Customer Satisfaction and Customer Perceived Value: Evidence from Iran's Software Industry. Journal of Management and Strategy, 3(3), 28-37. doi: 10.5430/jms.v3n3p28

Sheth, J. N., Newman, B. I., \& Gross, B. L. (1991). Consumption values and market choice. Cincinnati, $\mathrm{OH}$ : South Western Publishing Company.

Spreng, R., \& Mackoy, R. (1996). An empirical examination of a model of perceived service quality and satisfaction. Journal of Retailing, 72(2), 201-214.

Subrahmanyam, A., \& Raja, S. B. (2016). The effects of service quality on student loyalty: the mediating role of student satisfaction. Journal of Modelling in Management, 11(2), 446-462.

Swarbrooke, J., \& Horner, S. (2007). Consumer Behaviour in Tourism. USA: Elsevier Ltd.

Sweeney, J. C., Soutar, G. N., \& Johnson, L. W. (1997). Retail service quality and perceived value. journal of consumer services, 4(1), 39-48.

Tourism Malaysia. (2017). Malaysia Tourism Statistics in Brief. Retrieved March 18, 2017, from http://www.tourism.gov.my/statistics

Wang, X., Zhang, J., Gu, C., \& Zhen, F. (2009). Examining Antecedents and Consequences of Tourist Satisfaction: A Structural Modeling Approach. Tsinghua Science and Technology, 14(3), 397-406.

Woodruff, R. (1997). Customer Value: The Next Source of Competitive Advantage. The Journal of the Academy of Marketing Science, 25(2), 139-153.

Wu, H.-C., \& Li, T. (2014). A Study of Experiential Quality, Perceived Value, Heritage Image, Experiential Satisfaction, and Behavioral Intentions for Heritage Tourists. Journal of Hospitality \& Tourism Research, doi: 10.1177/1096348014525638

Yu, H. S., Zhang, J. J., Kim, D. H., Chen, K. K., Henderson, C., Min, S. D., \& Huang, H. (2014). Service Quality, Perceived Value, Customer Satisfaction, and Behavioral Intention Amog Fitness Center Members Aged 60 Years and Over. Social Behavior and Personality, 42(5), 757-768.

Zeithaml, V. A. (1988). Consumer perceptions of price quality, and value: A means-end model and synthesis of evidence. Journal of Marketing, 52(3), 2-22. 